\title{
Parents Communication to Down Syndrome in Online Learning During Pandemic
}

\author{
Kurniawaty May Sugiarto ${ }^{1 *}{ }^{*}$ Mutiah $^{2}$ \\ ${ }^{1,2}$ Universitas Negeri Surabaya \\ *Corresponding author. Email: $\underline{\text { may.17041184008@mhs.unesa.ac.id }}$
}

\begin{abstract}
Communication is an important need in human life in establishing relationships with other people. In communicating, a communicator must be able to convey the content of the message well and can be understood by the communicant. As is the case when communicating with children with special needs, one of them is with children with Down syndrome who require special communication. This study describes how the interpersonal communication of parents with children Down syndrome in online learning during the pandemic with a case study of parents with students Down syndrome at Down Syndrome School (DSS) QIS Surabaya. This study uses a model of interpersonal communication effectiveness developed by Joseph A. Devito using a qualitative research approach through phenomenological methods. The results of this study are Interpersonal Communication conducted by parents to children with Down syndrome paying attention to aspects of humanist communication, namely the elements of openness, empathy, supportive attitude, positive and equal communication. Down syndrome children while accompanying children to learn online using open communication, accepting all the feelings and spirits of unstable Down syndrome children. Then parents use positive and descriptive language and often provide support to increase children's confidence. When accompanying children to learn online, parents empathize with the child's condition so they don't force the child to quickly understand the lesson. Parental communication to children with Down syndrome is also equal, parents do not feel superior. On the other hand, parents position themselves as friends for children with Down syndrome.
\end{abstract}

Keywords: Interpersonal Communication, Parents, Down Syndrome, Online Learning

\section{INTRODUCTION}

Communication is an activity that cannot be avoided by every individual, according to Joseph A. Devito which means The process of sending and receiving messages between two persons, or among a small group of persons, with Some effect and some immediate feedback, namely interpersonal communication is the process of sending and receiving messages between two people or between small groups of people with feedback [1]. This is in line with Mulyana's opinion which states that interpersonal communication is face-to-face communication that allows participants to capture both verbal and nonverbal reactions [2]. Communication is not only interpreted as an exchange of verbal messages but more than that there is an instructional process in an ongoing communication. Instructional presents many symbols that can be interpreted in various ways. In instructional communication the five senses are the most widely used channel. In essence, in the ongoing communication process, communication tends to be dynamic and there is a rapid change in communication participants. In the context of instructional communication, all communication participants can become communicators as well as communicants [3].

According to Joseph A. Devito, there is a humanistic approach to the effectiveness of interpersonal communication, namely: Openness (openness), Empathy (empathy), Supportiveness (support), Positiveness (positive feeling), and Equality (similarity) [4]. These four humanistic approaches to interpersonal communication aim to foster and maintain social relationships. Humanist interpersonal communication approach involves all the human senses which enrich the communication process. The humanist approach is one way that can deliver effective communication between the actors. Even this humanist approach can also be applied to communicate with children with special needs, one of which is Down syndrome.

Down syndrome is a genetic disorder with distinctive physical characteristics. Mental retardation in children with Down syndrome results in delays in the development of motor, psychomotor and cognitive aspects [5]. Thus, families, especially parents, have an important role in helping the development of the ability of children with Down syndrome. Communication is a tool between parents and children with Down syndrome to understand each other. With effective communication in the family, it is possible for children with Down syndrome to get the first learning about social interaction and find their identity. So it is expected that children with Down syndrome are motivated to interact with the surrounding environment. As parents of children with Down syndrome, they must also prioritize their education. In addition to fulfilling the right to education lished by Atlantis Press SARL. 
for children, by sending down syndrome children to special schools, they will be handled by competent teaching staff so as to help improve the abilities of down syndrome children better. One of the special schools for children with Down syndrome is Down Syndrome School (DSS) QIS Surabaya.

In general, direct learning is more effective between teachers and children with Down syndrome, but the pandemic has made face-to-face learning become online. Online learning for children with Down syndrome is a difficult challenge for teachers and children themselves. During online learning, teachers cannot directly communicate with their students. Parents are the spearhead of successful learning at home during the pandemic. In conditions of online learning, of course, parent-child communication is more intensive. Families, especially parents, play a major role in delivering the success of children's education with Down syndrome [6]. How is the interpersonal communication of parents with their Down syndrome children, especially in the aspect of online learning assistance during the pandemic. This study uses a qualitative approach, a qualitative approach is suitable to see the form of parental communication when accompanying children with Down syndrome learning online. Research with a qualitative approach puts forward objectivism based on real data in the field [7]. While the research method is phenomenology with data collection techniques in the form of interviews and observations. There are four informants in this study. Informants are parents of children with Down syndrome.

\section{METHODS}

In this research, the researcher used descriptive qualitative research. By analyzing events, circumstances, social phenomena that exist in society. Documentation as evidence of events in research. Field analysis was obtained from the results of observations, interviews, and documentation.

\section{RESULTS AND DISCUSSION \\ 3.1. Form Of Parents' Communication with Down Syndrome Children}

In their daily life, children with Down syndrome often have difficulty speaking and arranging the right words to say. Children with syndrome in communicating use verbal (oral/written) and nonverbal (movements/signs), but in their daily life, children with Down syndrome use verbal communication more often because since childhood they are accustomed to communicating using verbal rather than nonverbal. On the other hand, they are not speech impaired or deaf so that the use of verbal language is the main way of communicating.

As a parent, it is obligatory to understand every child's behavior and movements when the child wants to express something. In their daily life, parents of children with Down syndrome communicate verbally.
Communication takes place both ways and gets feedback when parents often invite him to communicate every time. In this study, the research respondents were parents with children with Down syndrome. In the daily communication of parents use verbal language more often and get used to spoken language from childhood because children with Down syndrome are not deaf or speech impaired, children with Down syndrome dominant understand verbal language better when they are used to communicating.

In addition to verbal interpersonal communication, parents of children with Down syndrome also communicate nonverbally or use sign language because sometimes Down syndrome children do not understand what other people mean when they invite them to communicate using verbal language. Children with special needs with Down syndrome generally have IQs below average but they are great imitators. If from the beginning they have been accustomed to verbal and they understand, they no longer need sign language, but if a child with Down syndrome does not understand verbal language, it must be accompanied by sign language to understand the meaning conveyed.

In the communication that takes place between parents and children, down syndrome is equipped with gestures. Such as hand signals, gestures, and facial expressions. Due to the limitations that Down syndrome children have, they will only focus on one person they are talking to (unable to multitask). Although children with Down syndrome have limitations, instinctively they can still convey messages in their own way. In the conversation that occurs, the dialogue takes place more intimately, and is more personal but the communication is more serious. Basically there are no big obstacles for Down syndrome children to communicate with, the communication barrier is not in Down syndrome children but in how much parents accept their Down syndrome children's condition [8].

During the pandemic, parental communication with their child with Down syndrome is more about learning, because schooling is conducted online. The way parents retransmit the lesson messages given from the teacher is certainly different from everyday communication. If parents accompany a child with Down syndrome properly, this child can follow the lesson well and can even do complex tasks [9]. Therefore, a certain approach is needed so that learning can be accepted by children with Down syndrome.

\subsection{Communication of Parents and Down Syndrome Children in Online Learning}

During online learning, parents accompany children with Down syndrome intensively, using two-way or twoway communication. dyadic. In this communication, parents and children with Down syndrome prioritize the sense of sight. Parents maintain their child's concentration and focus with eye contact. With eye contact, children with Down syndrome can focus on 
being able to process information and receive it as well as possible. If the sense of sight does not function properly and does not focus on what is being communicated, it will cause a failure to understand the information. The communication strategy of parents when accompanying children with Down syndrome online learning can be seen from the following humanist communication approach.

\subsection{Openness}

In communication, it will be easier to understand if each participant in the communication is open. One of the weaknesses of communication is the lack of openness [10]. Being open here is letting others know about what we are thinking or feeling. An open attitude in communication states that open interpersonal communication to others indicates the person has a positive self-concept [11]. Children with Down syndrome are, of course, more open with their parents, so when online learning, children with Down syndrome are more free to express their misunderstandings about the lessons they receive. Children with Down syndrome also express their feelings when online lessons take place, for example feeling tired, not wanting to learn and being bored. Openness is reciprocal or reciprocal [12], that is, if each other wants to open up information to each other in communication activities. Openness can also be seen from the attitude of parents who can put themselves on a par, as developed by Devito in the humanist model of interpersonal communication which states that openness in communication can make communicators feel comfortable, because no one feels superior or inferior.

\subsection{Empathy}

Accompanying children with mental retardation and limitations requires special techniques and patience. Likewise for parents of children with Down syndrome, although parents have recognized their child's character from a young age, in the context of accompanying online learning, parents are not necessarily equipped with the abilities of a teacher for children with special needs. So parents must cultivate a high sense of empathy. Empathy is the ability to sense feelings from the perspective of others, to build healthy interpersonal relationships [13]. In the practice of parents when accompanying children with Down syndrome, empathy always affects the way they communicate.

In online learning, children with Down syndrome often feel lazy and their enthusiasm decreases. Parents try to understand by creating a pleasant atmosphere, the empathy given by parents does not always obey what the Down syndrome child feels but instead looks for the root of the problem that makes the Down syndrome child bored or less enthusiastic in learning online. What parents do is not to force them, but instead to provide variations in learning by means of playing outside. Parents are willing to take the time to accompany their children to play. This condition is a concrete sense of empathy from parents in responding to the feelings experienced by their Down syndrome children when learning online.

\subsection{Support and Positive Attitude}

Effective interpersonal communication is with a supportive attitude between parents who work with teachers for children with Down syndrome. When at home parents create an environment that is safe, comfortable, fun, and full of positive feelings. In giving a sense of security and comfort, parents can do it by building closeness with children such as giving affection through caresses or hugs. Creating an atmosphere that is descriptive and not evaluative will lead to a supportive attitude and the formation of self-concept in children.

A positive attitude in the form of praise or appreciation needs to be done so that communication can run effectively. In order to achieve effective communication, parents need to give children a reward if the child does something that makes them proud. Ibu Lili, one of the informants of this study stated in an interview that it is important to appreciate the slightest achievements of children with Down syndrome. Lili said that children with Down syndrome have moods that are easy to change, therefore parents must have a positive attitude and always provide support.

Children with Down syndrome who are often appreciated will be more enthusiastic when learning online and be confident. Based on the observations of researchers, the benefits of online learning will make the bonding between parents and children stronger. Bonding between parents and children presents a positive attitude and atmosphere from parents to children and vice versa. Parents try to always be by the side of down syndrome children so that communication is more effective during learning.

\subsection{Equality}

In preventing the chain of transmission of the corona virus, schools issue policies in the implementation of online education. This means that parents replace the role of teachers in accompanying children to study at home. During this pandemic, parents are very important partners in the education of their children. Parents are also required to be directly involved in assisting children with Down syndrome when doing school assignments. School assignments include activities that stimulate children's motor development. So, when parents accompany their children to train their motor skills, parents participate in carrying out tasks from school. When children play, parents also position themselves as friends, they play with children with Down syndrome. Therein lies the equality shown by parents. Parents when accompanying children to learn online position themselves like children. Parents not only accompany but also participate in doing what the school has assigned to their children. 
The attitude of equality shown by parents next is to position children with Down syndrome like normal children. Parents want their children to have a high self-concept, although physically and mentally they are different, but parents help their children to have the same abilities as normal children. Parents do not spoil their children by reason of the limitations they have. This is done so that their children are able to be independent and can live in society.

\section{CONCLUSION}

The conclusion of parental interpersonal communication with children with down syndrome in online learning during a pandemic is that parents apply effective communication with the following elements:

a. Openness in communicating with parents with down syndrome children. Parents receive complaints, feelings of their children when learning online. The feeling of boredom, tiredness, lack of enthusiasm that arises from children with Down syndrome during online learning is a form of open communication that is appreciated by parents.

b. Supportive and positive attitude. Parents use more descriptive positive language than evaluative.

c. Empathy in communication is carried out by parents according to the condition of the child with down syndrome.

d. Equality of communication is built by parents so that children with Down syndrome when learning online feel comfortable like friends.

\section{REFERENCES}

[1] Joseph A. Devito, Communication between people, Fifth. Professional Books, 1997.

[2] Deddy Mulyana, An Introduction to Communication Studies. Bandung: PT Remaja Rosdakarya, 2005.

[3] Mutiah, "Instructional Communication Between Teachers and Children With Different Abilities in the Inclusion School," in Proceedings of the 3rd International Conference on Social Sciences (ICSS 2020), 2020, pp. 377-381, doi: https://dx.doi.org/10.2991/assehr.k.201014.080.

[4] A. Liliweri, Interpersonal Communication. Bandung: PT. Citra Aditya Bakti, 1991.

[5] A. Moh, Orthopedagogics for Children with Mental Requirements. Bandung: Ministry of Education and Culture RI, 1995.

[6] W. Sri M, "PARENT PARENTING IN EFFORTS FOR ESTABLISHING INDEPENDENT CHILDREN DOWN SYNDROME $X$ CLASS D1/C1 at SLB NEGERI 2 PADANG (Case Study at SLB Negeri 2 Padang)," E-JUPEKhu (Journal of Science. Special Educators), vol. 3, no. 3, p. 742, 2014, doi: https://doi.org/10.24036/jupe39110.64.

[7] Gumilang Surya Galang, "QUALITATIVE RESEARCH METHODS IN THE FIELD OF GUIDANCE AND COUNSELING," J. Focus on Counseling, vol. 2, no. 2, p. 148, 2016, doi: https://doi.org/10.52657/jfk.v2i2.218.

[8] Isnawijayani, "PARENTS COMMUNICATION FOR CHILDREN WITH DOWN SYNDROME," J. Inov., vol. 13, no. 1, p. 30, 2019, doi: https://doi.org/10.33557/jurnalinovasi.v13i1.60 8.

[9] Elysa rosalina, "Keep Down Syndrome Children Healthy and Active During a Pandemic," National KBR Variety, 2020. https://kbr.id/ragam/102020/jaga_anak_down_syndrome_tetap_sehat_d an_aktif_saat_pandemi/103788.html.

[10] DS Pratiwi Srie W, "INTERPERSONAL COMMUNICATION BETWEEN STUDENTS IN SCHOOL AND THEIR IMPLICATIONS FOR GUIDANCE AND COUNSELING SERVICES," Counselor J. Ilm. Counseling, vol. 2, no. 1, p. 325, 2013, doi: https://doi.org/10.24036/02013211268-0-00.

[11] U. Syofia, "Soft Skill of Language Teachers in the Classroom: Analysis of DeVito Humanistic Interpersonal Communication Model," in International Conference on Language, Literature, and Education (ICLLE 2018), 2018, p. 170, doi: https://dx.doi.org/10.2991/iclle-18.2018.27.

[12] K. Uswatun, "Understanding the Openness of Interpersonal Communication in Online Conversations," Cult. Studs. IMC Media, vol. 3, no. 1, p. $17, \quad 2011, \quad$ doi: http://dx.doi.org/10.26623/themessenger.v3i1. 194.

[13] K. Muhammad, "RELATED EMPATHY AND INTERPERSONAL COMMUNICATION WITH QUALITY OF LIFE," J. Psychostudia Univ. Mulawarman, vol. 3, no. 1, p. 39, 2014, doi: http://dx.doi.org/10.30872/psikostudia.v3i1. 